\title{
The Use of Freshwater Sapropel in Agricultural Production: A New Frontier in Kenya
}

\author{
Sylvia I. Murunga $\mathbb{D}^{1}{ }^{1}$ Eliud N. Wafula, ${ }^{2}$ and Joseph Sang ${ }^{3}$ \\ ${ }^{1}$ Department of Agricultural and Biosystems Engineering, Jomo Kenyatta University of Agriculture and Technology, \\ P.O. Box 62000-00200, Nairobi, Kenya \\ ${ }^{2}$ Department of Botany, Jomo Kenyatta University of Agriculture and Technology, P.O. Box 62000-00200, Nairobi, Kenya \\ ${ }^{3}$ Department of Soil, Water and Environmental Engineering, Jomo Kenyatta University of Agriculture and Technology, \\ P.O. Box 62000-00200, Nairobi, Kenya
}

Correspondence should be addressed to Sylvia I. Murunga; smurunga@jkuat.ac.ke

Received 4 May 2020; Accepted 18 July 2020; Published 31 July 2020

Academic Editor: Othmane Merah

Copyright ( $) 2020$ Sylvia I. Murunga et al. This is an open access article distributed under the Creative Commons Attribution License, which permits unrestricted use, distribution, and reproduction in any medium, provided the original work is properly cited.

\begin{abstract}
Opportunities for sustainable agriculture development in Kenya which heavily depends on healthy soil and soil microbial diversity can be found in the promotion of organic farming. The increasing populations, higher demands for animal and plant products, climate change impacts, and weather conditions necessitate novel ideas and technologies to try reverse the adverse effects of excessive use of inorganic fertilizers and to maximize the potential of the land. Sapropel, a promising biological deposit from freshwater lakes, has found its limelight in its use in agricultural crop production as a soil conditioner and biofertilizer. This could be an ultimate practice for sustainable food and energy production in Kenya. This review aims at presenting information in the literature about the potential use of the organic fertilizer based on sapropels in intensified crop production and their main effects on plant growth. It discusses soil fertility, the composition of sapropels, and their application and advantages in agricultural production. It is evident from the review that sapropel can be considered as a resource that is valuable with wide application possibilities in agriculture. Sapropel can present an important contribution to the solution of the conservation of the fertility of the soil for integrated nutrient management systems to maintain agricultural productivity and help in environmental conservation.
\end{abstract}

\section{Introduction}

In Kenya, agriculture is very important in economic growth, contributing $33 \%$ of the gross domestic product (GDP) and $27 \%$ of the GDP indirectly through multisectoral linkages $[1,2]$. It also provides jobs to more than $40 \%$ of the total population, majority of which or $70 \%$ are rural dwellers [3]. Primary production plays an important part in maintaining the country's food security and contributes to improving nutrition through the production of safe, diverse, and nutrient-dense foods, while the industrial and horticultural crop subsectors are key foreign exchange-earners [4]. The sector also promotes nonagricultural economy including manufacturing, providing inputs and markets for nonagricultural operations such as building/construction, transportation, tourism, education, and other social services, thus enhancing agricultural productivity, and market access can help reduce poverty, particularly in rural areas [5-7].

A variety of challenges constrains the agricultural sector in Kenya. Reduction in agricultural production due to low input use, unsustainable soil, and water practices and the decreasing size of average land holdings $[4,8]$ are on the rise. Sufficient supply of crop nutrients partly influences the ability to improve productivity, although sustainability of agricultural systems is an important global issue [9]. Common ways of increasing efficiency and obtaining a better quality of product recovery in agricultural activities involve fertilizer application [10]. Nonorganic fertilizers mainly contain phosphate, nitrate, ammonium, and potassium salts. Kenya, for instance, has been utilizing fertilizers heavily for many years to boost her agricultural productivity. A large amount of agricultural budgets is allocated to 
subsidize fertilizers in the hope of improving national food production. The high level of fertilizer applications is vital to supply necessary food for the ever-increasing population and to meet higher demands for animal and plant products.

\section{Soil Fertility}

Crop yield in developing nations, particularly amid resource-poor farmers, has been constrained by soil infertility [11]. Soil contains an intricated ecosystem with high microbial diversity, which takes part in the recycling of nutrients and promotion of the development of healthy plants [12]. It also plays a role in the physical breakdown and biochemical transformation of complex molecules of dead material into simpler organic and inorganic molecules [13]. However, the microbiome can be influenced by the cultivation methods and environmental conditions resulting in alterations in the soil characteristics [14]. Nutrients are a key constituent of the ability of the soil to host plants and to generate plant yields. The soil fertility and availability of nutrients to plants are governed by the soil's parent rock and its physiochemical and biological properties [15]. It depends on the climate, vegetation, and the history of land use. Unfavourable soil conditions can result in nutrients in the soil becoming chemically bound (phosphorus) or physically fixed (potassium), making them virtually inaccessible to plants even though they remain in the soil $[9,16]$. Overreliance on chemical fertilizers could lead to severe soil acidification, nutritional imbalance, deterioration of the rhizosphere microecological environment, and further increase in the activity of heavy metal ions in soil [17]. Apart from lowering production, the eroded soils find their way into the water bodies causing siltation and eutrophication, hence an environmental hazard. Needed, therefore, are measures to maintain soil quality through good farming principles [9]. The prospective biological fertilizers would play a crucial part in sustainability and productivity of the soil and also in the environmental protection as they are ecofriendly and cost-effective inputs to the farmers [18]. Regarding these threats, researchers are anxious to find inexpensive, environmentally friendly, and practical ways to overcome fertilizer toxicity problems [11].

Sustainable land management and the conservation of soil and water can bring the organic matter to the soil, creating a means of compensating for continuous humus mineralization and present an opportunity for raising the level of humus content in the soil [13]. If preference is given to measures that improve soil humus content, nutrient, and energy cycle, agricultural intensification can be achieved [9]. This, in turn, improves the soil's nutrient storage capacity and nutrient availability to plants [19]. Improving humus content also helps to lay the foundation for further fertilization; thus, increased activity of soil microorganisms that accompanies the build-up of humus is of particular significance [12].

\section{Composition and Characteristics of Sapropel}

Sapropel also known as biodeposit is freshwater organic-rich mud sediment formed from the remains of plankton, water plants, and other marine-dwelling organisms involved in the transformation of mineral components influenced by various microorganisms $[20,21]$. Sapropels have a complex chemical composition with a broad range of values and depend on the geographical position of the region of occurrence [22]. Due to the organic-rich nature of sapropel, it is commonly used in the amendments of different soils to increase nitrogen, phosphorous, humus, and microelements' content. It is clean and efficient ecologically friendly natural material used in agriculture as biofertilizer and soil conditioner [20]. Worldwide, accumulation, formation, and intensive use of sapropel in agriculture and energy have been reported in temperate regions of Asia and Europe especially in Latvia, Bulgaria, Ukraine, Russia, Lithuania, Scandinavian Peninsula, Poland, France, Germany, and Belarus and Canada and the USA from the continent of America in the Great Lakes region [23] and most Middle East countries such as Jordan and Saudi Arabia [24].

As illustrated in Figure 1, sapropel consists of three main components: water about 60-90\% [26], mineral substances consisting of microelements manganese $(\mathrm{Mn})$, copper $(\mathrm{Cu})$, boron (B), zinc ( $\mathrm{Zn})$, iodine (I), chromium $(\mathrm{Cr})$, silver $(\mathrm{Ag})$, barium (Ba), titanium (Ti), molybdenum (Mo), and beryllium (Be), among others, and macroelements including nitrogen, silica, calcium, magnesium, iron, aluminium, potassium, phosphorus, and sulfur $[25,26]$. Presence of these substances in the soil improves the humus content thus preventing erosion and eventually restoring soil fertility by improving the soil structure. Additionally, sapropel also contains organic substances with organic matter ranging from 15 to $90 \%$ by weight, organic carbon not less than $40 \%$, and moisture content ranging between 60 and $90 \%$ [25, 26]. Sapropel also contains many biologically active substances such as watersoluble vitamins $\mathrm{A}$ (retinol), $\mathrm{B}_{1}$ (thiamine), $\mathrm{C}$ (ascorbic acid and dehydroascorbic acid), $\mathrm{B}_{2}$ (riboflavin), $\mathrm{B}_{3}$ (niacin), $\mathrm{B}_{6}$ (pyridoxine), $\mathrm{B}_{12}$ (cyanocobalamin), provitamin for vitamin $\mathrm{A}$ ( $\beta$-carotene), and $\mathrm{B}_{9}$ (folic acid) and fat-soluble vitamins $\mathrm{E}$ ( $\alpha$-tocopherol), $\mathrm{D}$, and $\mathrm{P}[23,25]$. The natural water-soluble amino acids contained in sapropels are histidine, glutamine, glycine, valine, arginine, aspartate, alanine, serine, leucine, isoleucine, phenylalanine, tyrosine, lysine, methionine, threonine, and cysteine. Natural enzymes include catalase, peroxidase, reductase, protease, urease, and xanthine oxidase, while the humic complex includes humic and fulvic acids $[15,20]$. Humic acids are the largest group of organic substances and are dark brown [23]. They have adhesive properties and thus associated with minerals in the soil, which significantly improves the soil structure and affects the growth and development of plants $[20,23,25,26]$.

The phytohormones such as gibberellic acid, cytokinin, ethylene, abscisic acid, brassinosteroids, and derivatives of indole-3-acetic acid found in sapropels affect plant growth and development [26]. Sapropel is characterized by a low amount of carbohydrate; the organic matter in sapropel contains $6-25 \%$ hemicellulose and $1-8 \%$ cellulose, and these can be used in the production of fertilizers, relevant in agriculture and horticulture as well as additives in animal feed [23]. Sapropel contains high amounts of bitumen which is characterized by fatty acids, steroids, paraffin, wax, 


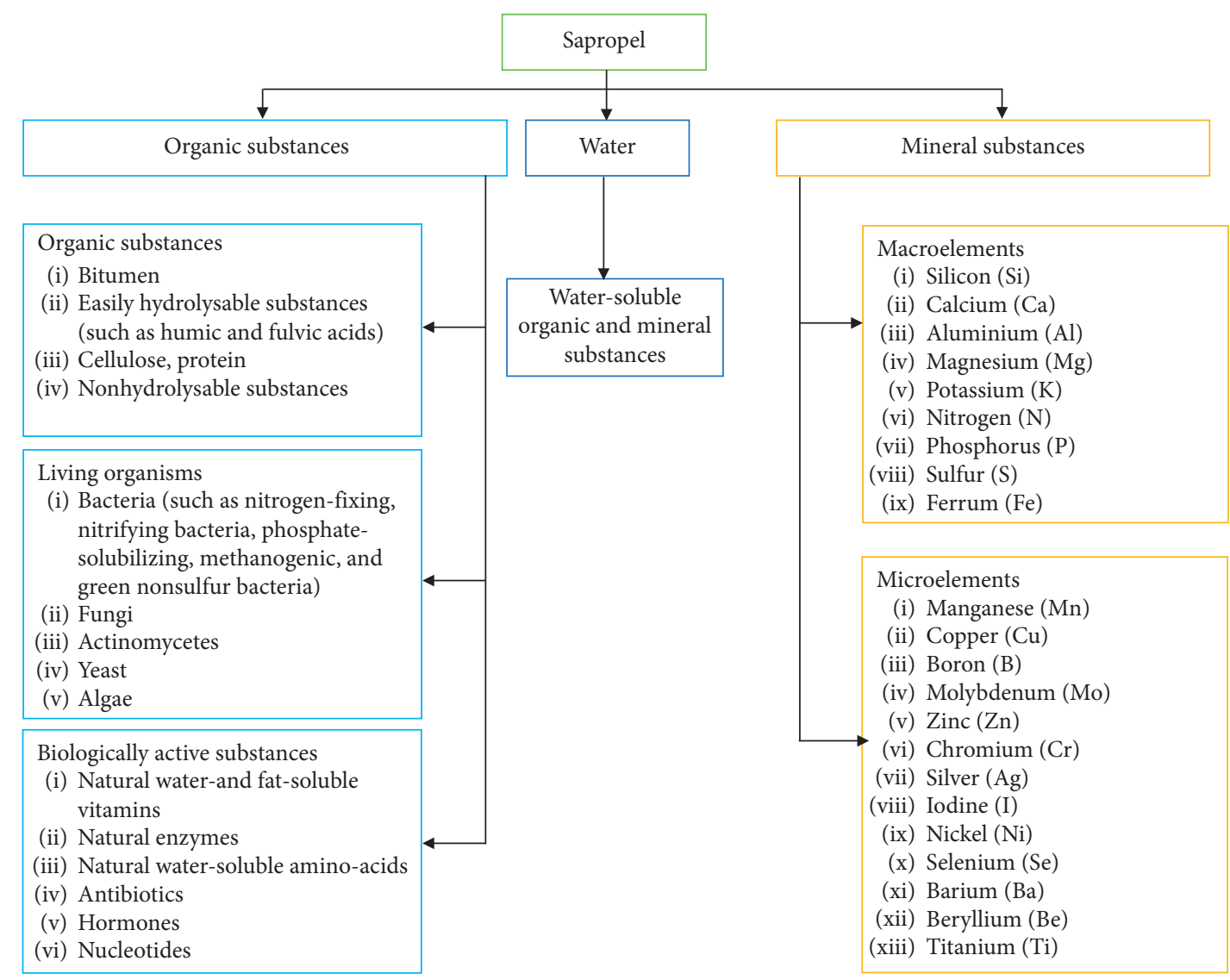

FIgURE 1: Composition of sapropel (adapted from Stankevica et al. and Blečić et al. [23, 25] with modifications).

glycerol, hydrocarbons, and other nonhydrolysable substances [23]. Bitumen in sapropel plays an inhibitory role against various microorganisms with antioxidant activity [23]. Another important active component of sapropel is antibiotics, mostly synthesized by fungi and actinomycetes, which promote nitrogen transfer to the form available to plants [23].

Living organisms constitute important biological components of freshwater ecosystems. The most predominant living organisms transforming the complex organic matter and minerals in these ecosystems are the prokaryotes. Studies show freshwater sapropel is highly populated with microorganisms ranging between $5.2 \times 10^{3}$ and $6.9 \times 10^{6}$ colony forming units (CFU) per gram of dry matter [27]. It was further noted that the depth of the sediment determines the number and composition of the organisms, i.e., they decrease with increase in depth of sediments. The most significant group of microorganisms found in sapropel is antibiotic producers (fungi and actinomycetes) and vitamin producers (bacteria and algae) $[23,27]$. Also found in the sediment are facultative anaerobes and or aerobes such as Micrococcus sp., Rhodococcus sp., Agrobacterium-related organisms, nitrogen-fixing groups (such as Azotobacter and Arthrobacter, among others), sulfur-reducing bacteria (Deltaproteobacteria) and methanogenic Euryarchaeota. Fe (III)-reducing bacteria like Geobacter sp. [24, 28], Cyanobacteria, and other plant growth-promoting bacteria belonging to Gammaproteobacteria and Bacilli [29-31] have also been found in sapropel. Therefore, the presence of living organisms is important in decomposition and transformation of organic substances into individual components available to the plants.

\section{Use of Sapropel in Agricultural Production}

Recent studies show various ways of sapropel applications in different sectors of the economy, especially in agriculture, medicine, and industry, as shown in Figure 2. In this review, our focus will be the use of sapropel in agriculture.

One area in agriculture where sapropel is applied is in the production of animal feed; this technology has been widely studied in Lithuania and Belarus for improvement of animal feed mixtures [23]. Sapropel enhanced feed which has the potential to improve animals' liver and stomach functions, blood formation, and circulation and reduces the disease occurrence and increases resistance of animals towards adverse environmental conditions. The key to these applications is in the high concentration of proteins, vitamins, enzymes, and other biologically active substances contained in sapropel. Studies by Gutikov et al. [32] showed that fodder enriched with sapropel led to increased efficiency of nutrient uptake and digestion in pigs. In the study by Myarikyanov and Uspenskaya [33], cattle were fed with a basal diet without or with sapropel; on average, the daily body weight gain was 532 and $445 \mathrm{~g}$ without or with sapropel. 


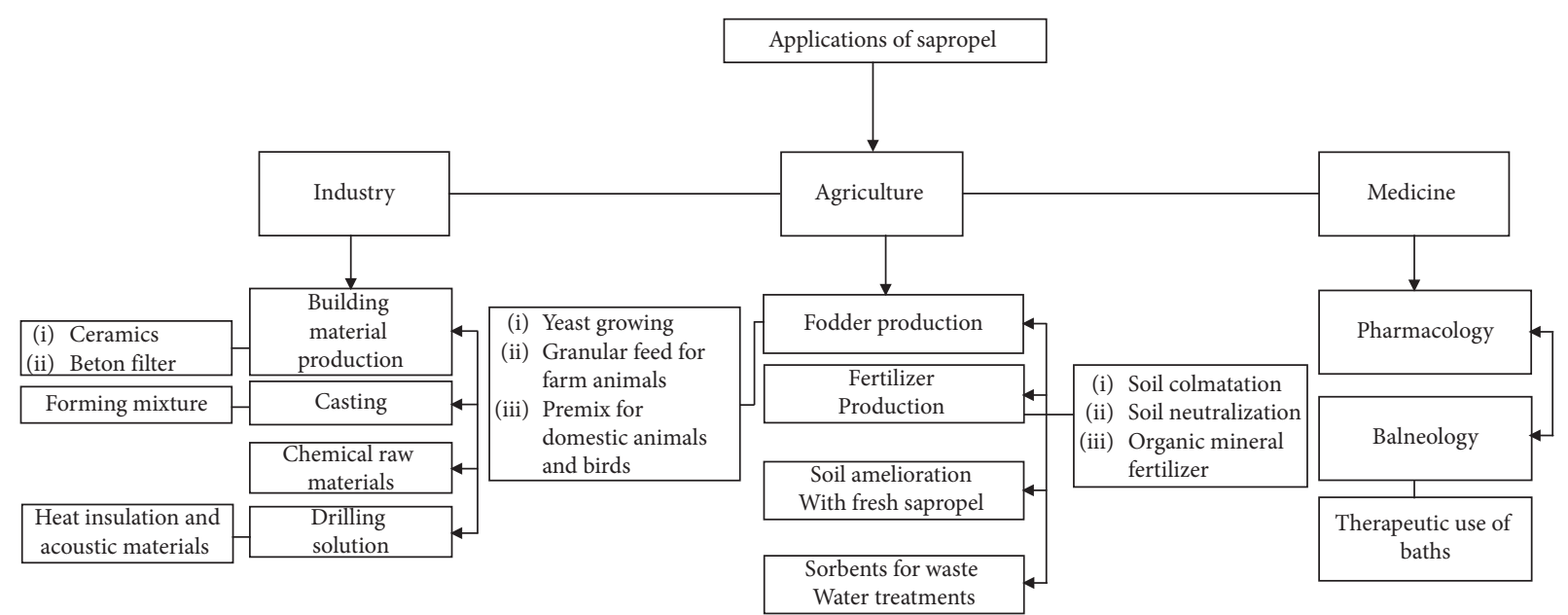

Figure 2: Applications of sapropel in different sectors of the economy (adopted from Stankevica et al. [23]).

One of the needs for sustainable agriculture is the development and use of plant fertilizers based on organic waste and renewable natural resources. In this respect, organic fertilizers are of great interest [24]. Traditionally, different types of organic fertilizers, e.g., manure, compost, and, recently, vermicompost, have been used. Sapropel has found its limelight in its use in agricultural crop production. Although the use of natural organic fertilizers from raw materials such as peat, sapropel, and brown coal [34] has increased during the last decades, there are limited data on the use of sapropel technology in many countries with tropical climates, especially in Africa, even though sapropel application is linked to increased yields of agricultural products $[25,34]$. Plants would generally benefit from the rise in soil organic matter, stimulation of microbiological activity, and plenty of mineral nutrients that will be made available to the plant as a result of incorporating sapropel as a fertilizer [24]. Table 1 shows the characteristics of a sapropel sample based on the fresh mass analysis. The microorganisms and enzymes contained in the biodeposit can revive dead ground, thus reactivate soil functions and give highly fertile properties by forming humus [22]. Microorganisms play a vital role in plant growth by affecting the activity of organic substrates. This has been linked to the availability of vital microorganisms in the soil that engage in nitrification, denitrification, and solubilization of phosphorus biodeposit, thus presenting an opportunity to provide organic fertilizers.

The preparation of soil substrates/growth media in the form of mixtures with peat, sludge, and any kind of composted biowaste $[32,35]$ is among the common uses of sapropel in agriculture. Recent studies show that the use of sapropel as a fertilizer can increase the barley yields by 15 to $20 \%$ and of potatoes by 25 to $30 \%$ [33]. More recent studies show that treatment of the soil with the organic fertilizer lowered the contents of cadmium $(\mathrm{Cd})$, lead $(\mathrm{Pb})$, and arsenic (As) in tea leaves significantly. Additionally, organicbased fertilizers had a positive impact on the content of the amino acids of tea and $\mathrm{pH}$ of the soil as a result of increased relative abundance of microorganisms belonging to Burkholderiales, Myxococcales, Streptomycetales, Nitrospirales,
TABLE 1: Characteristics of the sapropel sample according to certified analysis on a fresh mass basis.

\begin{tabular}{lcc}
\hline Parameter & Unit & Value \\
\hline Organic matter & $\%$ & $73.3 \pm 0.9$ \\
Total $\mathrm{P}\left(\mathrm{P}_{2} \mathrm{O}_{5}\right)$ & $\%$ & $0.15 \pm 0.02$ \\
Total N & $\%$ & $2.8 \pm 0.3$ \\
$\mathrm{~K}$ & $\%$ & $0.22 \pm 0.01$ \\
$\mathrm{As}$ & $\mathrm{mgkg}^{-1}$ & $0.73 \pm 0.07$ \\
$\mathrm{Fe}$ & $\mathrm{mgkg}^{-1}$ & $7745 \pm 775$ \\
$\mathrm{Hg}$ & $\mathrm{mgkg}^{-1}$ & $0.30 \pm 0.04$ \\
$\mathrm{Cr}$ & $\mathrm{mgkg}^{-1}$ & $23 \pm 2$ \\
$\mathrm{Cd}$ & $\mathrm{mgkg}^{-1}$ & $1.1 \pm 0.1$ \\
$\mathrm{Ni}$ & $\mathrm{mgkg}^{-1}$ & $18 \pm 1$ \\
$\mathrm{~Pb}$ & $\mathrm{mgkg}^{-1}$ & $9.5 \pm 0.1$ \\
$\mathrm{Cu}$ & $\mathrm{mgkg}^{-1}$ & $23 \pm 2$ \\
$\mathrm{Fulvic}$ acid & $\%$ & 10.1 \\
$\mathrm{Humic}$ acid & $\%$ & 5.4 \\
\hline $\mathrm{Adopt}$
\end{tabular}

Adopted from Grantina-ievina et al. [24].

Ktedonobacterales, Acidobacteriales, Gemmatimonadales, and Solibacterales [17].

In south-west Siberia, Naumova et al. [36] studied the effect of sapropel-amended soil on the yield of field tomatoes. The results generally showed that the sapropel amendment did not influence tomato fruit yield, but instead increased lycopene content in fruits by $80 \%$ from 19 up to $34 \mathrm{mg} / \mathrm{kg}$, thus improving fruit quality. Thus, soil microbiological properties, mineralization of organic matter, and nitrogen immobilization were shown to be more responsive to sapropel in addition than soil chemical properties. Research in the Middle East countries determined the application of the organic fertilizer based on sapropel and peat as a source of fertilizer and as a soil conditioner on the pretreatment of soil in greenhouses and on cucumbers in greenhouses which led to yield increase. An experiment on plants that were lagging in their development advanced and surpassed other plants in appearance when treated with the organic-mineral fertilizers (OMF). In other areas, the sapropel-based fertilizer was very effective in the early stages of 
fruiting with the optimal application rate of 1 litre per $10000 \mathrm{~m}^{2}$ [37].

Research carried out in the Middle East countries on the use of peat and sapropel based on organic-mineral fertilizers (OMF) as either a fertilizer or as a soil conditioner on cucumbers in greenhouses led to increase in yield. Similarly, a significant increase of about $44 \%$ per hectare in the yield of different wheat genotypes was achieved after using a liquid humic fertilizer derived from sapropel (potassium humate) [38]. The growth activity of tomatoes, beetroot, Swedish turnip, and carrot plants as a result of the use of freshwater sapropel was studied [24]. It was established that other than the mineral nutrients, sapropel also contained unspecified substances that contributed to the plant growth activities in the seedling growth tests. In this study, BioDeposit Agro (BDA) sapropel that contains the substrate with ability to enhance plant growth was found ideal with a very low growth-inhibiting component. BDA promoted the growth of both hypocotyl and radicle in all the tested seedlings. However, it was noted that the growth stimulation of the radicle was more by $10 \%$ compared to hypocotyl growth except for tomato seedlings. Also, variations in BDA concentration did not have any significant effect on hypocotyl growth [24].

In Kenya, undocumented data show the application of BDA in different regions including Tala in Machakos. BDA has been used on bananas, maize plantation, vegetables, coffee plantations, hydroponic cow feeds, and poultry farming. The results indicate that the BDA contributes positively to the quality of produce and also increases the yield.

\section{Advantages of Soil Amendment Based on Sapropel}

Addition of sapropel to soil may change not only soil acidity but also can increase the moisture level of soil as well as total porosity, independently from meteorological conditions. The use of sapropel as a soil fertilizer can improve soil physical properties better than limestone or farmyard manure applications. Season by season, the crop productivity increased in higher level after applications of carbonate sapropel as compared to limestone due to sapropel's mineral content and plant nutrition potential [39]. A study by Angelova et al. [40] compared the effects of soil amendments with phosphorous compounds, organic fertilizers, and sapropel on the quantity of the phyto-accessible forms of lead $(\mathrm{pb})$, zinc $(\mathrm{Zn})$, and cadmium $(\mathrm{Cd})$ and their uptake by triticale. The results indicated that the effect of the soil amendments on the mobile forms of the three elements were specific without a clear trend. A clear tendency, however, for the reduction of these three elements was observed with the use of natural fertilizers. The study also established that the absorption of $\mathrm{Pb}, \mathrm{Zn}$, and $\mathrm{Cd}$ by triticale was not related to the amount of mobile forms.

There is strong evidence that the use of fertilizers based on peat and sapropel increases the productivity of agricultural plants by $9-16 \%$, while the use of liquid humic microelement fertilizers provides an increase in the winter wheat grain yield up to 0.88 tons per ha, maize green mass up to 5.0 tons per ha, and maize grain up to 2.06 tons per ha [20]. Sapropels can be used as eco-friendly fertilizers as they add nutrients to soils.

Sapropel modifies and improves the soil structure, physical properties, soil aeration, viscosity, and capillary rise. It positively impacts on the hydrophilic-hydrophobic properties in fertilized soils, thus activates water movement and air mode in soils. Sapropel possesses water-consuming and water-retaining abilities, and it increases the humus content in the soil and activates soil processes [26, 41]. Consequently, slow solvability of product's acting compounds provides plants with balanced nutritional elements. Sapropel also increases the humus content besides participating in the cycling of nitrogen, phosphorus, sulfur, and other microelements within the soil. Being nonhazardous, sapropel fertilizer can activate many biochemical and chemical processes and pathways in plants, leading to an increase of self-purification. It can also stimulate seed sprouting and root growth of cultivated plants [26].

\section{Conclusion}

The world is becoming increasingly concerned about food shortage, and crop yield in developing nations, particularly amid resource-poor farmers, has been constrained by soil infertility. Upholding soil quality through basic principles of good farming can reduce some of these problems of land degradation, decreasing soil fertility, and rapidly declining production levels that occur in large parts of the world. The prospective biological fertilizers would play a crucial part in productivity and sustainability of soil and also in environmental protection as they are eco-friendly and cost-effective inputs to the farmers; therefore, using biological and organic fertilizers, which are low-input systems, can help in achieving sustainability of farms. Sapropel can be considered as a valuable resource with wide application possibilities in agriculture to enhance soil productivity, crop productivity, and quality.

\section{Conflicts of Interest}

The authors declare that they have no conflicts of interest.

\section{Acknowledgments}

The authors from Jomo Kenyatta University of Agriculture and Technology would like to thank the Japan International Cooperation Agency (JICA) for funding AFRICA-ai-JAPAN Project: Innovation towards enhancing food security through innovative biotransformation and value addition of major locally available biological resources (project no. JFY 2019/2020).

\section{References}

[1] MOALFI, Agricultural Sector Transformation and Growth Strategy: Towards Sustainable Agricultural Transformation and Food Security in Kenya, Government of Kenya, Nairobi, Kenya, 2018. 
[2] M. Mukumbu, S. Pagiola, D. Sellen, A. Winter-Nelson, G. Argwings-Kodhek, and F. Avillez, Agricultural Policy in Kenya, 2019.

[3] Government of Kenya, Agricultural Sector Transformation and Growth Strategy: Towards Sustainable Agriculture Transformation and Food Security in Kenya 2019-2029, Government of Kenya, Nairobi, Kenya, 2019.

[4] AGRA, "Africa agriculture status report: the business of smallholder agriculture in sub-saharan Africa (issue 5)," Alliance for a Green Revolution in Africa, vol. 5, p. 180, 2017.

[5] FAO, The State of Food and Agriculture 2018: Migration, Agriculture and Rural Developement, FAO, Rome, Italy, 2018.

[6] African Union Commission, Agenda 2063: The Africa We Want, Our Planet, African Union Commission, Addis Ababa, Ethiopia, 2015.

[7] Independent Group of Scientists Appointed by the SecretaryGeneral, "Global Sustainable Development Report 2019: ," The Future is Now-Science for Achieving Sustainable Development, United Nations, New York, NY, USA, 2019.

[8] FAO, FAO Country Programming Framework for Kenya 2014-2017, FAO, Rome, Italy, 2014.

[9] J. Kotschi, Adverse Impacts of Mineral Fertilizers in Tropical Agriculture. A Soiled Reputation, Heinrich Böll Found. WWF Ger., Gland, Switzerland, 2015.

[10] S. Savci, "Investigation of effect of chemical fertilizers on environment," APCBEE Procedia, vol. 1, pp. 287-292, 2012.

[11] A. Zaidi, E. Ahmad, M. S. Khan, S. Saif, and A. Rizvi, "Role of plant growth promoting rhizobacteria in sustainable production of vegetables: current perspective," Scientia Horticulturae, vol. 193, pp. 231-239, 2015.

[12] P. sas Lidia, "Beneficial microorganisms improving yield quality of horticultural crops and soil fertility," Applied Microbiology: Open Access, vol. 3, no. 3, p. 9315, 2017.

[13] R. Çakmakçi, F. Dönmez, A. Aydın, and F. Şahin, "Growth promotion of plants by plant growth-promoting rhizobacteria under greenhouse and two different field soil conditions," Soil Biology and Biochemistry, vol. 38, no. 6, pp. 1482-1487, 2006.

[14] K. Eiko, "Harnessing soil microbiome in sustainable agriculture," Applied Microbiology: Open Access, vol. 10, p. 50, 2018.

[15] A. Gałązka, K. Gawryjołek, A. Gajda, K. Furtak, A. Ksįżniak, and K. Jończyk, "Determination of structural biodiversity and functional and metabolic profiles in soil under long-term maize monoculture," Applied Microbiology: Open Access, vol. 4, 2018

[16] N. K. Fageria, "Soil fertility and plant nutrition research under field conditions: basic principles and methodology," Journal of Plant Nutrition, vol. 30, no. 2, pp. 203-223, 2007.

[17] W. Lin, M. Lin, H. Zhou, H. Wu, Z. Li, and W. Lin, "The effects of chemical and organic fertilizer usage on rhizosphere soil in tea orchards," PLoS One, vol. 14, no. 5, Article ID e0217018, 2019.

[18] K. Mohammadi and Y. Sohrabi, "Bacterial biofertilizers for sustainable crop production: a review," ARPN Journal of Agricultural and Biological Science, vol. 7, no. 5, pp. 307-316, 2012.

[19] M. Zhiyanski, M. Glushkova, L. Kirova, and E. Filcheva, "Quantitative and qualitative features of soil humus in mountain treeline ecosystems," Silva Balcanica, vol. 18, no. 1, pp. 5-23, 2017.

[20] L. Agafonova, I. Alsina, G. Sokolov et al., "New kinds of sapropel and peat based fertilizers," Proceedings of the International Scientific and Practical Conference, vol. 2, no. 20, 2015.
[21] E. Bakšienè, M. A. Fullen, and C. A. Booth, “Agricultural soil properties and crop production on lithuanian sandy and loamy cambisols after the application of calcareous sapropel fertilizer," Archives of Agronomy and Soil Science, vol. 52, no. 2, pp. 201-206, 2006.

[22] V. A. Rumyantsev, A. S. Mityukov, L. N. Kryukov, and G. S. Yaroshevich, "Unique properties of humic substances from sapropel," Doklady Earth Sciences, vol. 473, no. 2, pp. 482-484, 2017.

[23] K. Stankevica, Z. Vincevica-Gaile, and M. Klavins, "Freshwater sapropel (gyttja): its description, properties and opportunities of use in contemporary agriculture," Agronomy Research, vol. 14, no. 3, pp. 929-947, 2016.

[24] L. Grantina-ievina, A. Karlsons, and U. Andersone-ozola, "Effect of freshwater sapropel on plants in respect to its growth-affecting activity and cultivable microorganism content," Zemdirbyste-Agriculture, vol. 101, no. 4, 2014.

[25] A. Blečić, B. Railić, R. Dubljević, D. Mitrović, and V. Spalevic, "Application of sapropel in agricultural production," Agricultural and Forest Meteorology, vol. 60, no. 2, pp. 243-250, 2014.

[26] L. W. Szajdak and A. Sakowicz, "Sapropel in agriculture," International Peat Congress, vol. 37, 2012.

[27] K. Stankevica, O. Muter, and Z. Vincevica-Gaile, "Microbial community analysis of sapropel (gyttja) derived from small overgrowing lakes in the eastern Latvia," in Proceedings of the 2nd Congress of Baltic Microbiologists, pp. 66-82, Hyogo, Japan, 2015.

[28] L. Haller, M. Tonolla, J. Zopfi, R. Peduzzi, W. Wildi, and J. Poté, "Composition of bacterial and archaeal communities in freshwater sediments with different contamination levels (Lake Geneva, Switzerland)," Water Research, vol. 45, no. 3, pp. 1213-1228, 2011.

[29] D. F. R. Cleary, M. R. S. Ferreira, N. K. Bat, A. R. M. Polónia, N. C. M. Gomes, and N. J. de Voogd, "Bacterial composition of sponges, sediment and seawater in enclosed and open marine lakes in Ha Long Bay Vietnam," Marine Biology Research, vol. 16, no. 1, pp. 18-31, 2020.

[30] I. Iliev, M. Marhova, S. Kostadinova et al., "Metagenomic analysis of the microbial community structure in protected wetlands in the Maritza River Basin," Biotechnology \& Biotechnological Equipment, vol. 33, no. 1, pp. 1721-1732, 2019.

[31] L. Zhang, T. Zhao, Q. Wang, L. Li, T. Shen, and G. Gao, "Bacterial community composition in aquatic and sediment samples with spatiotemporal dynamics in large, shallow, Eutrophic Lake Chaohu, China," Journal of Freshwater Ecology, vol. 34, no. 1, pp. 575-589, 2019.

[32] K. D. Gutikov, V. K. Pestis, and V. F. Kovalevskij, "Efficacy of feed additives with sapropel in rations of pigs," AGRIS, vol. 2, pp. 95-100, 2006.

[33] S. P. Myarikyanov and O. N. Uspenskaya, "Genesis and utilization of sapropel in agriculture," Sel'skokhozyaǔstvennaya Nauka, vol. 3, pp. 125-132, 1990.

[34] G. Sokolov, L. Szajdak, and I. Simakina, "Changes in the structure of nitrogen-containing compounds of peat-, sapropel-, and brown coal-based organic fertilizers : restoration of peatland soils for agricultural use," Agronomy Research, vol. 6, no. 1, pp. 149-160, 2008.

[35] N. S. Gruda, "Increasing sustainability of growing media constituents and stand-alone substrates in soilless culture systems," Agronomy, vol. 9, no. 6, p. 298, 2019.

[36] N. Naumova, T. Nechaeva, N. Smirnova, Y. Fotev, and V. Belousova, "Effect of sapropel addition on selected soil properties and field tomato yield in Southwest Siberia," Asian 
Journal of Soil Science and Plant Nutrition, vol. 1, no. 3, pp. 1-11, 2017.

[37] M. Ostrovskij, I. Zeidan, S. V. Tsukanov, A. Zeidan, I. Uptis, and J. Apse, "Application of organic fertilizers based on sapropel and peat in countries of middle east," European Agrophysical Journal, vol. 1, no. 3, p. 114, 2014.

[38] R. Shahryari and V. Mollasadeghi, "Increasing of wheat grain yield by use of a humic fertilizer," Advances in Environmental Biology, vol. 5, no. 3, pp. 516-518, 2011.

[39] D. Daugviliene, A. Burba, and E. Bakšiene, "Changes of sandy loam cambisol properties at application for calcareous sapropel and limestone," Journal of Food, Agriculture and Environment, vol. 12, no. 1, pp. 491-495, 2014.

[40] V. R. Angelova, K. I. Ivanov, and S. V. Krustev, "Effect of phosphorous, organic and sapropel amendments on lead, zinc and cadmium uptake by triticale from industrially polluted soils," in Proceedings of the 23rd Annual International Conference on Soils, Sediments and Water, vol. 13, pp. 253-265, Chania, Greece, 2007.

[41] L. W. Szajdak, Bioactive Compounds in Agricultural Soils, Springer International Publishing, Cham, Switzerland, 2016. 